\title{
SOY DEVELOPMENT UNDER DIFFERENT WAYS OF APPLICATION OF PHOSPHORUS IN DIRECT PLANTING SYSTEM
}

Thainara Estigaribia ${ }^{1}$, Marcio Osvaldo Lima Magalhães ${ }^{2}$, Roberto Antonio Savelli Martinez ${ }^{2}$, Adalberto Santi $^{2}$, Marcus Vinicius Gonçalves Lima ${ }^{2^{*}}$

'Bacharel em Agronomia da Universidade do Estado de Mato Grosso (UNEMAT), Tangará da Serra - MT, Brasil.

2Professor Doutor do curso de Agronomia da Universidade do Estado de Mato Grosso, Tangará da Serra, Mato Grosso, Brasil.

*marcuslimagro@gmail.com

Recebido em: 15/05/2020 - Aprovado em: 15/06/2020 - Publicado em: 30/06/2020 DOI: 10.18677/EnciBio_2020B43

\begin{abstract}
This work aimed to verify the development of the soybean crop under different phosphorus placements, in the sowing line and broadcasted. The study was carried out in at Marape Agropecuária farm, the property regularlly performs the no-tillage system using two managements in phosphate fertilization, with a field that receives application of phosphorus by broadcasting and another field application in the sowing lines. The depths analyzed were in layers of $0.0-5.0 ; 5.0-10.0 ; 10.0-15.0$ and 15.0$20.0 \mathrm{~cm}$ to determine the amount of phosphorus available in the soil, in addition to the complementary $\mathrm{pH}$ analysis. The following were determined: effective root system depth in flowering phase and physiological maturation phase, thousand-grain weight, pod number per plant, number of grains per pod and soybean yield. Although there was a significant difference in phosphorus availability at the first depth, that difference did not reflect in terms of soybean plant development. Soybean plants development and productivity are not influenced under different ways of phosphorus applications on direct planting systems.
\end{abstract}

KEYWORDS: Cerrado, phosphorus cycling, phosphorus fertilization.

\section{DESENVOLVIMENTO DA SOJA SOB DIFERENTES FORMAS DE APLICAÇÃO DE FÓSFORO EM SISTEMA DE PLANTIO DIRETO}

\section{RESUMO}

Este trabalho teve como objetivo verificar o desenvolvimento da cultura da soja, sob as formas de aplicação de fósforo na linha de semeadura e a lanço. O estudo foi realizado na fazenda Marape Agropecuária, a propriedade realiza o sistema de plantio direto utilizando dois manejos na adubação fosfatada, com talhão que recebe aplicação de fósforo a lanço e outro talhão aplicação na linha de semeadura. As profundidades analisadas foram em camadas de 0,0-5,0; 5.0-10.0; 10.0-15.0 e 15.0$20.0 \mathrm{~cm}$ para determinar a quantidade de fósforo disponível no solo, além da análise complementar do $\mathrm{pH}$. Foram determinados ainda: profundidade efetiva do sistema radicular na fase de floração e fase de maturação fisiológica, peso de mil grãos, número de vagens por planta, número de grãos por vagem e produtividade de soja. Embora tenha havido uma diferença significativa na disponibilidade de fósforo na ENCICLOPÉDIA BIOSFERA, Centro Científico Conhecer - Goiânia, v.17 n.32; p. 474 2020 
primeira profundidade, essa diferença não refletiu em termos de desenvolvimento das plantas de soja. O desenvolvimento e a produtividade das plantas de soja não são influenciados sob diferentes formas de aplicação de fósforo em sistemas de plantio direto.

PALAVRAS-CHAVE: adubação fosfatada, Cerrado, ciclagem de fósforo.

\section{INTRODUCTION}

The Midwest region in Brazil has great economic importance in relation to grain production, being soybean (Glycine max (L.) Merril) one of the main crops. The soils of that region have as their main characteristics their mineralogy composed by kaolinites and oxides, which have high phosphorus $(P)$ fixation capacity and unavailability, bringing implications for growth and development for plant species (SOUSA et al., 2010; NICCHIO et al., 2019). The phosphorus deficiency limits crop development to around 30\% in arable land (MacDONALD et al., 2011).

This element acts in various ways on plant metabolism, such as the formation of Adenosine Triphosphate molecules (ATP), root system development (MALAVOLTA, 1997), as well as photosynthesis, respiration, and gene transfer (STAUFFER; SULEWSKI, 2003), maintenance of membrane structures, synthesis of biomolecules and formation of high-energy molecules, also helping in cell division, enzyme ativity and carbohydrate metabolism (RAZAQ et al., 2017).

Phosphorus is the element that most limits productivity in the cerrado soils due to the low levels present on the soil (SOUSA et al., 2004), low mobility and its high adsorption forming poorly soluble Fe and $\mathrm{Al}$ complexes, as well as its binding with the surface of clay minerals. The distribution and liberation of phosphorus in soil solution is mainly controlled by iron-aluminum oxides and hydroxides (LI et al., 2016). Due to these characteristics in the soils of the cerrado, there is a decrease in fertilization efficiency, so a larger application of phosphate fertilizers is necessary (MACHADO et al., 2011, SCHONINGER et al., 2013).

The most used modes of application of $\mathrm{P}$ for grain production are surface broadcastign, with or without incorporation; in the sowing furrow; in pits and bands (SOUSA et al., 2004). The application of phosphate fertilizers may influence the increase of plant rooting, and assist in the redistribution of $P$ in the soil, as a result of decomposition, increasing the contents in deeper layers (OLIVEIRA JUNIOR et al., 2008).

Despite the recommendation of phosphate fertilization being in the planting furrow as the main management method for the nutrient, in the Cerrado, the broadcasting fertilization has become a widely used alternative (Nunes et al., 2011). However, little has been proven about the best management in the application of phosphate fertilizers. Thus, this work aimed to verify the development of the soybean crop under different phosphorus placements, in the sowing line and broadcasted.

\section{MATERIAL AND METHODS Location and characterization of the study area}

The study was carried out in the 2016/2017 cropping season at Marape Agropecuária farm, in Lucas do Rio Verde - MT, with altitude of $390 \mathrm{~m}$, with a Savannah Tropical climate, with two well defined seasons (rainy from October to April and dry from May to September). The annual average temperature is $25^{\circ} \mathrm{C}$ and average rainfall of $2333,0 \mathrm{~mm}$. The soil was classified as Dystrophic Red Yellow Latosol with clay texture (MOREIRA; VASCONCELOS, 2007). 
The property regularlly performs the no-tillage system using two managements in phosphate fertilization, with a field that receives application of phosphorus by broadcasting and another field application in the sowing lines. This management has been used for eight years for the same plots and with the same amounts of phosphate fertilization for two years, with $210 \mathrm{~kg}^{-1}$ of MAP (Monoammonium Phosphate) formulation and $160 \mathrm{~kg} \mathrm{ha}^{-1}$ of $\mathrm{KCl}$ (Potassium Chloride).

\section{Analyzes performed}

The evaluation method used was the one proposed by Loss et al. (2017), consisting of approximately $600 \mathrm{~m}^{2}$, for each plot corresponding to the application method, in which 5 transverse trenches were opened to measure the length of the root. After that, the collection of ten plants and soil samples in each area were performed to analyze the number of pods per plant, number of grains per pod and weight of 1000 grains. The yield of the two areas were obtained by the harvested grains by the owner in each field.

The depths analyzed were in layers of $0.0-5.0 ; 5.0-10.0 ; 10.0-15.0$ and 15.0 $20.0 \mathrm{~cm}$. The samples were collected to obtain Air Dry Fine Earth (ADFE) to determine the amount of phosphorus available in the soil, in addition to the complementary $\mathrm{pH}$ analysis.

The analyzes were performed at the University of Mato Grosso State (UNEMAT), Tangará da Serra Campus - MT, following the methodology recommended by Silva (2009), whose method used was Mehlich 1.

\section{Statistical analysis}

Variance analyzes were performed for the characteristics evaluated at the $5 \%$ probability level, using the Assistat software.

\section{RESULTS AND DISCUSSION}

The average phosphorus content as a function of phosphate fertilizer management and depth can be seen on Table1. It can be observed that there was variation only between the depth of $0-5.0 \mathrm{~cm}$, where the amount of phosphorus present in the soil was higher in the broadcast application in relation to the sowing line (Table 1). Regarding depth, it was observed that there was a decrease in phosphorus contents with increasing depth.

TABLE 1. Average amount of phosphorus in each treatment regarding depth and mode of application

\begin{tabular}{ccc}
\hline Depth $(\mathbf{c m})$ & \multicolumn{2}{c}{ Phosphorus contents $\left(\mathbf{c m o l c ~} \mathbf{~ d m}^{\mathbf{3}}\right)$} \\
\cline { 2 - 3 } & Sowing row & Broadcast \\
\hline $\mathbf{0}-\mathbf{5 . 0}$ & $19.42^{\star}$ & $28.671^{*}$ \\
$\mathbf{5 . 0}-\mathbf{1 0 . 0}$ & $14.70^{\mathrm{ns}}$ & $15.83^{\mathrm{ns}}$ \\
$\mathbf{1 0 . 0}-\mathbf{1 5 . 0}$ & $3.11^{\mathrm{ns}}$ & $4.76^{\mathrm{ns}}$ \\
$\mathbf{1 5 . 0}-\mathbf{2 0 . 0}$ & $1.76^{\mathrm{ns}}$ & $3.51^{\mathrm{ns}}$ \\
\hline ns = not significant at 5\% probability level; ${ }^{*}=$ significant at $\mathbf{5} \%$ probability level.
\end{tabular}

In a study, was found that the application of broadcasted phosphorus stood out between the control and application in the sowing line, only in the first soil layers analyzed $(0-5.0 \mathrm{~cm})$, the author concluded that the result was because the fertilizer 
concentration was higher due to the smaller volume of soil analyzed in that form of fertilization (MOTOMIYA et al., 2004).

Analyzing the vertical distribution of phosphorus in the soil under different application modes, including the interaction between combinations in the application mode, Barbosa et al. (2015) found similar results. At the depth of 0, $0-2.5 \mathrm{~cm}$ there was significant difference for the treatment with most of the broadcasted fertilizer $(100 \%)$, which presented larger quantities of available $P$. The motif was linked to the application site of $P$, since in the seeding line, $P$ was deposited at $6 \mathrm{~cm}$ depth and the broadcasted $P$ concentrated on the soil surface.

Formation of a soil superficial layer with high nutrient availability, mainly phosphorus is described by Rheinheimer and Anghinoni (2001). They claim that such behavior occurs due to the consecutive additions of fertilizer in the superficial layer and the non-revolving soil system (the no-tillage system) (NTS). P adsorption occurs primarily at the sites of lower lability, and then the remaining $P$ is redistributed into fractions retained with less energy and higher availability to plants (LI et al., 2016). Due to its low mobility, the consecutive additions of $P$ to the surface of the NTS have saturated the highest affinity sites for the element.

The decrease and similarity between application modes at depths below 5 $\mathrm{cm}$ can be explained by the low mobility of phosphorus in the soil.

Phosphorus application methods did not influence the effective depth of the root system during flowering as in the physiological maturation, one thousand grain mass and yield (Table 2). Although there was a significant difference in phosphorus availability at the first depth (Table 1), that difference did not reflect in terms of soybean plant development, this was probably because phosphorus levels in the seeding line management were sufficient to supply the need for the crop. The absence of difference between the two application modes can be explained by the long cultivation period of these areas, eight years with the same management.

TABLE 2. Effective root system depth in flowering phase (RSF) and physiological maturation phase (RSM), thousand-grain weight (TGW), pods number per plant (PPP), number of grains per pod (NGP) and soybean yield (Y)

\begin{tabular}{|c|c|c|}
\hline Analysis & Sowing row & Broadcasted \\
\hline RSF (cm) & $14.05^{\mathrm{ns}}$ & $13.30^{\mathrm{ns}}$ \\
\hline RSM (cm) & $14.95^{\mathrm{ns}}$ & $14.45^{\mathrm{ns}}$ \\
\hline TGW (g) & $182.00^{\mathrm{ns}}$ & $171.60^{\mathrm{ns}}$ \\
\hline PPP & $63.10^{\mathrm{ns}}$ & $59.50^{\mathrm{ns}}$ \\
\hline NGP & $128.20^{\mathrm{ns}}$ & $116.60^{\mathrm{ns}}$ \\
\hline$Y\left(\mathrm{~kg} \mathrm{ha}^{-1}\right)$ & $3609.60^{\text {ns }}$ & $3540.00^{\text {ns }}$ \\
\hline
\end{tabular}

ns = not significant at $5 \%$ probability level; ${ }^{*}=$ significant at $5 \%$ probability level.

In studies conducted by 17 years in the experimental area of Embrapa Cerrados, in Planaltina - DF, similar results were obtained. The author explains that during the $\mathrm{P}$ correction phase $\left(1^{\circ}\right.$ to $4^{\circ}$ crops) broadcasted fertilization provided greater efficiency in relation to the sowing line, since a natural phosphate source was used. However, after the area was corrected (maintenance fertilization) there was no difference between treatments (NUNES et al., 2015).

The slight variation in effective root system growth (ERSG) may be a result of its growth phases, as in the flowering phase the main root still grows vertically, but from the formation of the pods, this growth rate is reduced considerably until the harvest. 
Similar productivity on both areas can be explained by the critical phosphorus level in the soil, ie when the $P$ levels are above the critical, the probability of crop response is low or absent. However, when the levels are below the critical level, productivity in broadcasted fertilization areas has been lower when compared to row seeding (BARBOSA et al., 2015).

Superiority by nutrient concentration is determined by several factors, including soil $\mathrm{pH}$, being a direct measure of soil acidity (SPOSITO, 2008). Soil acidity will influence the charges of minerals present in weathered soils such as Oxisols. Acid soils, ie, with $\mathrm{pH}$ lower than 5.5, phosphorus is fixed as phosphate on the surface of kaolinites and Fe or Al oxides, being of low solubility (BROCH; RANNO, 2012). On Table 3 can be seen that the $\mathrm{pH}$ of the analyzed soils were all above 5.5, indicating that there was a higher phosphorus availability, since kaolinites are negatively charged.

TABLE 3. In-depth pH analysis of the two application modes

\begin{tabular}{ccc}
\hline Depth $(\mathrm{cm})$ & Sowing row & Broadcasted \\
\hline $0,0-5,0$ & 5,60 & 5,60 \\
$, 0-10,0$ & 5,70 & 5,60 \\
$10,0-15,0$ & 5,80 & 5,60 \\
$15,0-20,0$ & 5,60 & 5,70 \\
\hline
\end{tabular}

Because all $\mathrm{pH}$ levels were above 5.5 the $\mathrm{Al}^{+3}$ analysis was performed, however, as expected, their levels were below the values that affect plant growth and development.

\section{CONCLUSIONS}

Soybean plants development and productivity are not influenced under different ways of phosphorus applications on direct planting systems.

\section{REFERENCES}

BARBOSA, N.C.; ARRUDA, E.M.; BROD, E.; PEREIRA, H.S. Distribuição vertical do fósforo no solo em função dos modos de aplicação. Bioscience Journal, v.31, n.1, p.87-95, 2015. DOI: https://doi.org/10.14393/BJ-v31n1a2015-18196.

BROCH, D.L.; RANNO, S.K. Fertilidade do solo, adubação e nutrição da cultura da soja. Tecnologia e produção: soja e milho, 2011/2012.

GONÇALVES, J.L.M.; FIRME, D.J.; NOVAIS. R.F.; RIBEIRO, A.C. Cinética de adsorção de fósforo em solos de cerrado. Revista Brasileira de Ciência do Solo, v. 9, n. 2, p.107-111, 1985.

LI, Z.W.; TANG, H.W.; XIAO, Y.; ZHAO, H.Q.; LI, Q.X.; et al. Factors influencing phosphorus adsorption onto sediment in a dynamic environment. Journal Hydroenvironment Research, v.10, p.1-11, 2016. DOI: 10.1016 / j.jher.2015.06.002.

LOSS, A.; LOURENZI, C.R.; SANTOS JÚNIOR, E.; MERGEN JÚNIOR, C.A.; BENEDET, L.; et al. Carbon, nitrogen and natural abundance of ${ }^{13} \mathrm{C}$ and ${ }^{15} \mathrm{~N}$ in biogenic and physicogenic aggregates in a soil with 10 years of pig manure application. Soil And Tillage Research, v. 166, p. 52-58, 2017.

DOI: https://doi.org/10.1016/j.still.2016.10.007. 
MacDONALD, G.K.; BENNET, E.M.; POTTER, P.A.; RAMANKUTTY, N. Agronomic phosphorus imbalances across the world's croplands. Proceedings of the National Academy of Sciences, v. 108, n. 7, p. 3086-3091, 2011.

DOI: 10.1073 / pnas. 1010808108 .

MACHADO, V.J.; SOUZA, C.H.E.; ANDRADE, B.B.; LANA, R.M.Q.; KORNDORFER, G.H. Curvas de disponibilidade de fósforo em solos com diferentes texturas após aplicação de doses crescentes de fosfato monoamônico. Bioscience Journal, v. 27, n. 1, p. 70-76, 2011.

Available in: http://www.seer.ufu.br/index.php/biosciencejournal/article/view/7389.

MALAVOLTA, E.; VITTI, G.C.; OLIVEIRA, A.S. Avaliação do estado nutricional de plantas: princípios e aplicações. Piracicaba: Potafos, 1997. 319p.

MEURER, E.J.; RHENHEIMER, D.; BISSANI, C.A. Fenômenos de sorção em solos. In: MEURER, E.J. (Ed.) Fundamentos de química do solo. $3^{\text {a }}$ ed. Porto Alegre: Evangraf, 2006. p. 117-162.

MOREIRA, M.L.C.; VASCONCELOS, T.N.N. Solos e Paisagens. Cuiabá: Editora Entrelinhas, 2007. 222 p.

MOTOMIYA, W.R.; FABRICIO, A.C.; MARCHETTI, M.E.; GONÇALVES, M.C.; ROBAINA, A.D.; et al Métodos de aplicação de fosfato na soja em plantio direto. Pesquisa Agropecuária Brasileira, v. 39, n. 4, p. 307-312, 2004. DOI: 10.1590/S0100-204X2004000400002.

NICCHIO, B.; KORNDÖRFER, G.H.; PEREIRA, H.S.; ARRIETA, R.G.; NASCIMENTO, I.R.; et al. Fuentes alternativas de fósforo en suelos del "cerrado" cultivados con maíz (Zea mays). Pesquisa Agropecuária Pernambucana, v. 24, n. 1, p. 1-9, 2019. DOI: https://doi.org/10.12661/e1991242019.

NOVAIS, R.F.; ALVAREZ, V.H.V.; BARROS, N.F.; FONTES., R.L.F.; CANTARUTTI, R.B.; et al. Fertilidade do solo. 1nd ed. Viçosa, MG: Sociedade brasileira de ciência do solo; 2007.

NOVAIS, R.F. Phosphorus supplying capacity of previously heavily fertilized soils. Releigh, North Carolina State University, 1997.

NUNES, R.S.; SOUSA, D.M.G.; GOERDET, W.J.; REIN, T.A. Eficiência de uso do fósforo por soja e milho em Latossolo do Cerrado em função do sistema de manejo do solo e da adubação fosfatada por um longo período. XXXV Congresso Brasileiro de Ciência do Solo. Centro de Convenções, Natal-RN, 2015.

NUNES, R.S.; SOUSA, D.M.G.; GOERDET, W.J.; VIVALDI, L.J. Distribuição de fósforo do solo em razão do sistema de cultivo e manejo da adubação fosfatada. Revista Brasileira de Ciências do Solo, v. 35, p. 877-888, 2011. Available in: http://www.scielo.br/pdf/rbcs/v35n3/v35n3a22.pdf. 
OLIVEIRA JUNIOR, A.; PROCHNOW, L.I.; KLEPKER, D. Eficiência agronômica de fosfato natural reativo na cultura da soja. Pesquisa Agropecuária Brasileira, v. 43, n. 5, p. 623-631, 2008. DOI: http://dx.doi.org/10.1590/S0100-204X2008000500010.

RAZAQ, M.; ZHANG, P.; SHEN, H.L.; SALAHUDDIN. Influence of nitrogen and phosphorus on the growth and root morphology of Acer mono. PLoS One, v. 12, n. 2, e0171321, 2017. DOI: 10.1371 / journal.pone.0171321.

RHEINHEIMER, D.S.; ANGHINONI, I. Distribuição do fósforo inorgânico em sistemas de manejo de solo. Pesquisa Agropecuária Brasileira, v. 36, n. 1, p. 151160, 2001. DOI: http://dx.doi.org/10.1590/S0100-204X2001000100019.

SCHONINGER, E.L.; GATIBONI L.C.; ERNANI, P.R. Fertilização com fosfato natural e cinética de absorção de fósforo de soja e plantas de cobertura do cerrado. Semina: Ciências Agrárias, v. 34, n. 1 p. 95-106, 2013. DOI: 10.5433/16790359.2013v34n1p95.

SILVA, F.C. Manual de análises químicas de solos, plantas e fertilizantes. 2nd ed. Brasília DF. Editora: Embrapa, 2009.

SOUSA, D.M.G.; REIN, T.A.; GOERDET, W.J.; LOBATO, E.; NUNES, R.S. Fósforo. In: PROCHNOW, L.I.; CASARIN, V.; STIPP, S.R. (Eds.) Boas práticas para uso eficiente de fertilizantes: v. 2, nutrientes. Piracicaba: INPI - Brasil, 2010. p.67-132.

SOUSA, D.M.G.; LOBATO, E.; REIN, T.A. Adubação com fósforo. In: SOUSA, D.M.G.; LOBATO, E. Cerrado: Correção do solo e adubação. Planaltina, Embrapa Cerrados. 2004. p.147-168.

SPOSITO, G. The surface chemistry of soils. 2nd Ed. New York, Oxford University Press, 2008.

STAUFFER, M.D.; SULEWSKI, G. Phosphorus: essential for life. In: Simpósio sobre fósforo na agricultura brasileira, 2003, Piracicaba. Anais... Piracicaba: Potafos/Anda, 2003. 